\title{
Guidelines towards plausible interpretation of gospel parables
}

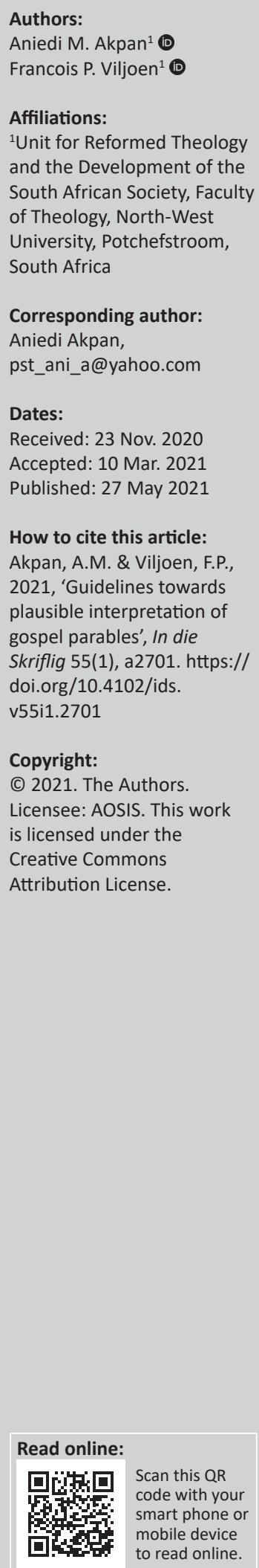

This study is undertaken against the backdrop of the polyvalence of parables and the resultant arbitrary conclusions reached by many interpreters of gospel parables. It is aimed to set guidelines towards plausible interpretations of these parables. It identified some factors that influence the understanding of the parables and thereby formulated principles for guiding the exegete to plausible conclusions. The genre parable was defined and understood to function metaphorically, implying that the true meaning of parables lies outside of their narrated domain (i.e. in a second, distinct domain). Eight principles were formulated to enhance credible parable exegesis and were explained with illustrations from New Testament parables. They included the need to acknowledge the openness of parables, as well as the need to interpret parables within specific gospel contexts. The attention of interpreters was also drawn to five pitfalls when seeking a plausible interpretation of gospel parables. It became clear that only in a holistic combination could these principles enhance the plausible interpretation of the gospel parables, while isolative considerations would most likely mislead the interpreter. In this article it is concluded that, although parables are polyvalent, this does not justify arbitrary interpretations; hence the need for gospel parable interpreters to take seriously the methods and principles that limit multiplicity and enhance plausibility of the parables' meanings.

Contribution: The contribution of this investigation lies in a canonical approach to gospel parables, and to set guidelines for plausible interpretation from such a stance. While it is recognised that earlier forms of parables, albeit in oral or written form, are of interest in historical critical investigations, the current study works with the forms of parables as embedded in specific gospel narratives.

Keywords: interpretation of gospel parables; hermeneutics; metaphor; narrative; canonical approach; how to understand parables of Jesus; biblical interpretation.

\section{Introduction}

Mark and Matthew assert that the parabolic mode of communication was central to Jesus' teaching (Mt 13:34; Mk 4:34). However, understanding of these texts was widely divergent in early Christianity (Viljoen 2019:1).

Zimmermann (2015:4-5) cites differences between parables in the parallel traditions of Matthew, Luke and the Gospel of Thomas (Gos. Thom.). ${ }^{1}$ Based on these comparisons, it is clear that the evangelists did not interpret (or use) particular parables in exactly the same way. There are occasions in which the same parable or two textually similar parables are employed in markedly different literary contexts or even with different terminology (e.g. the parable of the lost sheep [Mt 18:10-14; Lk 15:1-7]; the parable of talents or minas [Mt 25:14-30; Lk 19:11-27]).

Parables are enigmatic by nature and require explanation (Hultgren 2000:456). In the Septuagint (LXX), the term $\pi \alpha \rho \alpha \beta 0 \lambda \eta$ refers to a figure of speech of which the meaning is not obvious. In Psalms 78:2 (LXX 77:2), $\pi \alpha \rho \alpha \beta o \lambda \alpha i$ [parables] and $\pi \rho \circ \beta \lambda \eta \mu \alpha \tau \alpha$ [problems] are used in a synonymous parallelism. In Proverbs 1:5-6, $\pi \alpha \rho \alpha \beta$ o $\alpha$ í refer to sayings that require skills to be understood. Parables need interpretation (2 Esdr 4:47; Sir 47:15-17). However, this is no reason for the modern interpreter to impose random meanings on parables - a practice quite common to some emerging preachers. ${ }^{2}$ As is the case with general biblical interpretation, there are 1.John included none of these parables. Instead, he portrays Jesus as making use of rapoinia [figures], for example the image of the sheepfold (Jn 10:1-6), the door of the sheepfold (7-10), the good shepherd (10:11-18), and the vine and the branches (15:1-8).

2.In a three-part teaching serial, an online interpretation of the Parable of the Talents (Tompkins n.d.[a, b, c]) illustrates this issue. In the first part, Tompkins (n.d. a) asserts that the word talent means 'to bear' or something 'weighty', connecting it to a description of 'glory' as 'weight'; 
guidelines to be followed, as well as boundaries beyond which interpretation is questionable. Zimmermann's metaphor (2015:205) is apt: 'It is possible to identify clear boundaries for the playing field outside of which the game is no longer possible, where the ball is "out of bounds".' The point of departure in this article is that the narrative meshalim should be read within their narrative contexts (Gerhardsson 1991:325).

This article therefore attempts to outline guidelines that would make interpretation of the gospel parables credible. However, brief attention will first be given to the definition of parable as well as to a model for understanding the parable genre as metaphors.

\section{Definition of parable}

The following is Zimmermann's definition (2009) of a parable: ${ }^{3}$

A parable is a short narrative (1) fictional (2) text that is related in the narrative world to known reality (3) but, by way of implicit or explicit transfer signals, makes it understood that the meaning of the narration must be differentiated from the literal words of the text (4). In its appeal structure (5) it challenges the reader to carry out a metaphoric transfer of meaning that is steered by cotext and context information (6). (p. 170)

This definition has implications for this article, and two issues will be raised briefly here in that respect. First, the narrativity of parables implies that there is at least one action sequence or change of status either reported or imagined (Zimmermann 2009:171). This makes it necessary to pay attention to the narrative structure of parables.

Second, the metaphoricity of parables implies that a parable does not utilise meaning at the literary level of the text, but

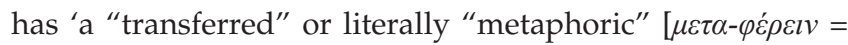
transfer] meaning' (Zimmermann 2009:172). It is necessary to note, then, that two domains of understanding come into transaction every time one is dealing with a parable. The first is the 'image providing' domain (German: bildspendender Bereich) while the other is the 'image receiving' domain (German: bildempfangender Bereich).

For biblical parables, in particular, the 'image providing' domain is usually constituted by the field of daily life and experience while the 'image receiving' domain is usually the religious or ethical sphere (Zimmermann 2014:7). ${ }^{4}$

(footnote 2 continues....)

hence, 'talents' in the story are as 'weighty' or 'valuable' as the glory of God is. In the second part, the 'talents' are for Tompkins (n.d. b) 'faith assignments' (cf. Eph 2 8-10). To avoid failure, a 'one talent' person should not presume to function in the role of the 'two talent' or 'five talent' person. In the third and final part, Tompkins (n.d. c) sees the talents as 'faith-gifts': the 'one-talent servant' is a 'faithstopper' (he buried his talent); the 'two-talent servant' is a 'faith-stepper' (although competent, he does not take initiative); and the 'five-talent servant' is a 'faithstarter' (competent, bold and an initiator [ $\operatorname{Pr} 28: 1]$ ).

3.Zimmermann's definition is based on the fact that parables for the modern reade are available in a textual form. However, it should be noted that this definition would not comply with the first hearers of the parables.

4.In the time of Jesus, religion was not a separate social institution, but intertwined with politics and the economy.

\section{'Metaphor' as model for understanding the gospel parables}

The transferred meaning, highlighted in the preceding section, suggests metaphor as a model for understanding the nature and function of the gospel parables in their narrative contexts. In apparent support of this assertion, Roth, Zimmermann and Labahn (2014) submit that 'the parables provide fertile ground for considerations of narrativity and metaphor'. Van der Watt (2009:325-326) shares the view that parables function as metaphors in the Bible. This study estimates these claims as perhaps some of the strongest statements that connect parable to metaphor.

What is the metaphorical significance of parables? Snodgrass (2008:28) says, 'The key is knowing when to stop interpreting. As with metaphor, parable interpretation is about understanding the limits - and the significance - of the analogy.' All through the history of parable interpretation, 'knowing when to stop interpreting' has been a daunting challenge. Scott (1989:49) explains that, based on the common notion that 'a parable is something laid beside, "parallel", so that the narrative is laid beside its referent', parables do not explicitly specify to the hearer or reader how to relate narrative to referent. This leaves the interpreter to figure out the extent of the mapping guided by such implicit rules or instructions as genre, narrative structure and the direction of transference. Akpan (2018:15) agrees with Scott that biblical parables generally do not specify their correspondence to their symbols and adds that the reader/hearer-responsibility might well serve as an explanation for some of the surplus details of meaning (including allegorising) accrued to parables.

Sequel to the limits on transference of meaning from the 'image providing' domain to the 'image receiving' domain is the fact that no single parable does everything, and hence the warning that no parable should be forced to address issues not its concern. Otherwise, understanding will be distorted. According to Snodgrass (2008:28): 'Insensitivity to the limits of analogy invariably leads to ruin in understanding'. The guidelines that follow attempt to place necessary limits on the interpretation of the New Testament parables.

\section{Hermeneutical principles for interpreting the gospel parables}

Zimmermann (2015) identifies two reasons for the diversity of interpretations of the gospel parables. According to him, the first reason is due to the nature of parables themselves. He states:

\footnotetext{
Understanding parables is clearly not simple, uncomplicated, or uncontroversial ... Parables are simply not clear or unambiguous. They neither follow the laws of philosophical or mathematical logic nor express simple platitudes. (p. 4)
}

By this he means that the interpretation exegetes make of a parable depends on the way they understand it. The second 
reason is due to exegetical methodology: 'Methods are hermeneutical keys, each of which opens a different lock in order to achieve understanding' (Zimmermann 2015:191). In other words, what one arrives at, depends on the method one employs in investigating the parable. ${ }^{5}$

In light of the above, this article recommends the following principles for parable exegesis:

- Correlate parabolic and non-parabolic biblical material.

- Interpret parables within particular gospel contexts.

- Seek out the parable's specific function in the teaching of Jesus.

- Acknowledge the openness of parables.

- Full-breadth analysis should be done on the parable.

- Interpret what is given, not what is omitted.

- Consider socio-historical background of the parables. ${ }^{6}$

- Pay attention to stock metaphors and symbols.

\section{Correlate parabolic and non-parabolic biblical material}

According to Snodgrass (2017:131), 'The correlation of parabolic and nonparabolic material increases confidence about what Jesus taught. ${ }^{7}$ Elsewhere he (Snodgrass 2008:30) states: 'If you cannot validate the teaching you think is in the parable from nonparabolic material elsewhere in the gospels, you are almost certainly wrong.' Accordingly, although the parables do not cover all the motifs in Jesus' New Testament teaching, 'it seems that all the subjects addressed in the parables are in some measure addressed in nonparabolic material'. In other words, the parables do not suddenly wake up to address novel subjects in the New Testament; rather, they are part of a wholesome teaching on the subject and serve to provide specific 'light' for understanding the subject. Therefore, to correctly interpret parables, exegetes need to check for balance between their interpretation and the general teaching of Jesus reported by the evangelists or even other teaching sections of the New Testament. ${ }^{8}$

For instance, an interpreter can boost understanding of the parable of the unforgiving servant (Mt 18:21-35) by studying Jesus' teaching on forgiveness, say, in Matthew 6:12, 14-15,

5.For example, Van Eck (2009:1-12) offers 'a social-scientific approach' for interpreting 'the parables of the Galilean Jesus'. His interest, and hence the method, is not
theological as such, but to follow a historical-critical route to recover the 'original' form of the parables as told by Jesus himself in his social setting before the evangelists made use of the stories.

6.It is often argued that, when reading the gospels as narratives, it should be read a-historically with a text-immanent approach (Viljoen 2018:2). Edwards (1997:6) argues that there should be no concern with the historical background. Only the world in the narrative, as constructed by the narrative, is relevant. Such a nonworld in the narrative, as constructed by the narrative, is relevant. Such a non-
referential view of a narrative assumes that the narrative does not reflect the real referential view of a narrative assumes that the narrative does not reflect the rea world. Although the narrative world of the gospels is not identical to reflections of
the world of Jesus or that of the evangelist, Edwards (1997) states that, 'Undoubtedly the narrative worlds of the Gospels are related in various ways ... to both the world of Jesus and the social world of the evangelist.' The reader must construct the real world from the narrative world.

7.This article does not, however, assume with Snodgrass that the gospels records are Jesus' ipsissima verba, or even that they are used by the evangelists in the same context as Jesus did. Elsewhere Snodgrass (2008:26) and Zimmermann (2015.189) context as Jesus did. Elsewhere, Snodgrass (2008:26) and Zimmermann (2015:189) authentic and authoritative, they cannot simply be equated to the ipsissima verba of Jesus.

8.As mentioned before, it should be noted that much of the parabolic and nonparabolic material are interpretations of the different evangelists, which might differ in certain cases. and vice versa. Matthew 18:21-35 says in pictures what Matthew 6:12, 14-15 says in words. Matthew 6:12 teaches that the justification for asking forgiveness of God is that one forgives another first. The unmerciful servant (who is a metaphor for a believer) in the parable failed the test of justification, for he came to the king (a metaphor for God) and secured forgiveness of a colossal debt, but went out to harass a colleague whose indebtedness to him was far less than the king had forgiven him (Mt 18:28-30). When the king was told of his unmerciful disposition, he invited him back and 'cancelled' the forgiveness, locked him up and instructed the jailers to torture him until he would have paid everything he owed (Mt 18:32-34). In the conclusion of the parable, Jesus, according to Matthew, says: 'This is how my heavenly Father will treat each of you unless you forgive your brother from your heart' (Mt 18:35). This is much the same as Matthew 5:14-15 where Jesus says:

For if you forgive men when they sin against you, your heavenly Father will also forgive you. But if you do not forgive men their sins, your Father will not forgive your sins. ${ }^{9}$

Conversely, the parable text addresses more than just forgiving; it also teaches an attitude of continually forgiving a brother or sister who repeatedly offends one (Mt 18:21-22), as well as truly forgiving the person from the heart (v. 35). In this way, the parable text expands the teaching on forgiveness in the Lord's Prayer. In fact, both texts can be read together for a sermon on Christian forgiveness.

Snodgrass (2017:140) highlights two merits of this principle of correlation, namely, in the first place, it helps to sift suggested meanings of parables. In his (Snodgrass 2017) words:

It is important to correlate parabolic and nonparabolic material in order to limit theories about the meaning of the parables. If the meaning suggested for a parable cannot be verified by nonparabolic teaching, it is unlikely to be true. (p. 140)

This postulation is apt. Parables are not independent of the rest of the canon; their interpretation therefore needs to consider the message of the canon in general, as well as that of other portions of the canon on the same subject matter.

In the second place, it provides multiple (or recurrent) attestation to some key themes in Jesus' teaching, for example, kingdom, eschatology, forgiveness, et cetera. According to Snodgrass (2017):

The coherence of parabolic and nonparabolic teaching on themes most of which are, if not unique, at least unusual, is significant, even foundational ... This underscores the importance of the parables for understanding Jesus. (p. 140)

This claim apparently asserts that the gospel parables address motifs that constitute Jesus' teaching in the New Testament. To that extent, interpretations that take the focus of a parable off this track are disputable.

9.In many cases, parables are framed by introductions ( conclusions ( conclusions ( $\dot{\varepsilon} \pi \mu n \theta i \alpha$ [afterthoughts]) that provide evaluations and interpretations.
Although some of these introductions and conclusions may have formed part of an original story, others were added by the evangelists (Viljoen 2019:1). 


\section{Interpret parables within particular gospel contexts}

Reinstorf (2006:145) calls for effort to interpret parables within their particular gospel contexts, as the evangelists did not reproduce a memorised text; but in accordance with their specific theological agenda "often "shaped" (or retold) the parables of Jesus to fit their situation'. Reinstorf (2006) also says:

The parables of Jesus as they feature in the Gospels are not loose, independent units, but form part of the greater message of each Gospel writer. The particular intent ${ }^{10}$ of the Gospel writer needs to be discerned, before the parable can be translated into the present day situations. (p. 145)

Snodgrass agrees on the need to carry on interpretation of parables within specific gospel contexts. He (Snodgrass 2008) says:

The parables are stories used twice ${ }^{11}$ - once by Jesus and then by the Evangelists. They are stories within larger stories, parables woven into the Gospel narratives. The narrative provides an interpretive field within which both the parables and the larger narrative shed light on each other. The parables were remembered because of their relevance in understanding the larger story. We must read stereoscopically for both the intent of Jesus and the intent of the Evangelists. (p. 26)

Herzog II (1994:3) agrees and says, 'As they stand in their present narrative settings, the parables serve the theological and ethical concerns of the evangelists.' In other words, the parables are not objectively reported by the evangelists, but are used where and how they are used for specific theological or ethical reasons. Similarly, for Zimmermann (2015:189), 'the macro-text' (apparently referring to the individual gospel) in which the parable is found, is crucial for determining the meaning of the parable within that specific context. In consequence, he prefers an approach to the parables that take account of 'the context of the source in which they have been transmitted (i.e. within a particular parable's macro-text)'.

In a text-immanent approach to the reading of gospels, parables should be read in terms of the narrative and theology of the specific gospel where it is found. ${ }^{12}$ The individual evangelists had a message to pass across, and selected and arranged materials that helped them deliver that message. In that sense, the message of a parable in, say, Mark, is bound to contribute to Mark's overall theology, and cannot be understood apart from that theology. The same goes for Matthew and Luke. Van der

\section{The challenge with this assertion is the proposed search for authorial intent. This can hardly be achieved. However, if parable researchers limit themselves to the communicative intent discernible from the text itself, Reinstorf's argument can be said to be both fitting and realistic.}

11.That the parables were used 'twice', should be understood as capturing the transition between Jesus' use and the evangelists' (canonical) use. Jesus, himself, might have used any given parable more than once, and between him and the evangelists, and even after the evangelists, the same parable could have been used at least once more. However, in terms of the oral tradition, a parable could have been used multiple times in multiple contexts.

12.A text-immanent approach examines the gospels as literary units (Viljoen 2018:2). Traditional historical-critical readings of the gospels focus on the origin, sociohistorical circumstances of it, their sources, forms, redaction, et cetera. One of the most fundamental limitations of such a historical critical paradigm is that it often disregards the narrative integrity of the gospels (Howell 1990:21).
Watt (2009:333) supports this thought: 'Parables should ... not be read in isolation or as individual narratives, but the message of the parables should be entered through the message of the Gospel ...'. It is important, then, to seek to understand how a parable fits into the theology of a given gospel text before drawing out its specific meaning.

\section{Seek out the parable's specific function in the teaching of Jesus}

According to Snodgrass (2008):

Context is a determiner of meaning - in the end the only determiner of meaning, for words themselves have only possible meanings apart from context. If the goal is to hear the voice ${ }^{13}$ of Jesus, some other context cannot work. (p. 26)

Accordingly, he rightly counsels the interpreter to seek the meaning of gospel parables in the context of the teaching of Jesus, which he says is actually 'the context of the parables'. In his (Snodgrass 2008) words:

If we cut the parables out of the context of Jesus' teaching, we can make them mean anything, which is precisely what has happened in a number of studies ... If we place parables in context of our choosing, we change them into something other than Jesus's communicative intent. (p. 26)

In this light, one can ponder many of the interpretations of the parable of talents (Mt 25:14-30) in which it is often used as a text for discussion on financial (or business) investment; not to mention the literal understanding of 'talents' within a contemporary English worldview (Akpan 2018:85-134). There are Scriptures that address work and investment quite alright, but one wonders if Matthew 25:14-30, within the context of Jesus' teaching, addresses work or investment. An apparent reason for understanding this parable in terms of work and investment is that the interpreters have by design or by default plucked it out of the context of Jesus' teaching in the respective gospels. Until they return to this context, they will continue to churn out such conclusions as noted here. For the records, interpreters may not be able to access the specific context of many (if not all) parables, but they lose virtually nothing, because the general context in the teaching of Jesus is available in the gospels and serves as a reliable framework for interpreting the parables.

\section{Acknowledge the openness of parables}

Parables are 'open' literary units. It is necessary, then, for the exegete of any parable text to realise from the outset that they are dealing with a text that can explode with 'a surplus of meaning' - to use the words of Lategan (2009:66). Others feel the same way about the potential meaning of parables. For Zimmermann (2009:173-174), parables are 'puzzles' and therefore lend themselves to reader-oriented and multiple interpretation. Both scholars also share the view that the polyvalence of the meaning of parables begins to manifest in the synoptic gospels and are undeniably present in contemporary exegesis.

13.This should be understood as the "voice' of Jesus as available in the gospels; not a historical-critically reconstructed 'voice' (see Van Eck 2009:4). 
Taking any two parallel parables side by side, one notices that the evangelists did not use them in exactly the same way, for example, the parable of the lost sheep (Mt 18:10-14; Lk 15:1-7). Matthew uses the story to illustrate the need to be committed to the sustenance of little children in the Christian faith:

See that you do not look down on one of these little ones. For I tell you that their angels in heaven always see the face of my Father in heaven ... In the same way your Father in heaven is not willing that any of these little ones should be lost. $(18: 10,14)$

Luke employs the story differently in the face of the dissatisfaction of Jewish religious leaders with Jesus' interaction with 'tax collectors and "sinners"' (Lk 15:1), and concludes with the way heaven responds to the repentance of a sinner:

I tell you that in the same way there will be more rejoicing in heaven over one sinner who repents than over ninety-nine righteous persons who do not need to repent. (v.7)

Such legitimate polyvalence, as seen between Matthew 18:10-14 and Luke 15:1-7 above, should make it easy to understand why Zimmermann rejects Jülicher's single-point interpretation model. In his words:

No matter how 'illuminating' the imagined scene may appear to be at first glance, the process of transferral is anything other than unambiguous ... The occurrence of transferal ... implies inexplicitness for it is indeed pre-structured through transfer signals in the text and context. However, the completion of the task - the actual finding of meaning on a higher level - is left to the reader. (Zimmermann 2009:174, [author's own emphasis])

It is also apt that Zimmermann (2009:175) further says that it is this openness that makes parables 'active in interpretation that is, they evoke an interpretation', and allows interpreters to 'read the parables of Jesus from different standpoints, areas of interest and motivations'. Dodd's classic definition similarly allows a parable to '[leave] the mind in sufficient doubt about its precise application to tease it into active thought' (1961:5, [author's own emphasis]).

\section{Full-breadth analysis should be done on the parable}

Parables are narratives, notwithstanding that they are fictional. That being the case, every necessary element of narrative analysis is needed to understand them. For Snodgrass (2008:25): ' ... All the regular practices for good interpretation of texts are in force when interpreting parables.' These include paying close attention to the parable's structure and thought development, as well as to features of symmetry or parallelism between components. Snodgrass also considers comparative analysis for parables that have parallel counterparts in other gospels.

As earlier asserted, this is a call to deal with parables as narrative texts and structured communication to which the regular principles of narrative analysis apply.
In a similar fashion, Zimmermann (2015:192) points out that, because parables are 'artistically designed texts', the narrative analyst needs to ask such questions that border on the way the text is constructed, the syntactical and structural features that are evident, the reader-oriented literary devices being used, et cetera. He also postulates that, because parables are both narrative and metaphorical in nature, these two aspects must be given serious attention.

Narrative analysis of parables, Zimmermann (2015:193) suggests, involves examining the 'literary devices concerning the discourse, the manner of recounting the story (e.g. focalization, implied narrator and reader, time and space matters)'. It also involves analysing the relation between 'narrative time' and 'narrated time', 14 the identity of characters and the way their personalities are developed, the way the plot unfolds, and so on.

Regarding the metaphoricity of parables, the transaction between two dissimilar semantic fields, context-based access to meaning and the contributions of 'external transfer signals, such as introduction (e.g. 'The kingdom of God is like ...' [Mt 13:31,33]) and conclusion (e.g. 'So ...' [Mt 12:45; 13:49; 20:16]; 'In the same way ...' [Mt 18:14]), are factors that must be taken seriously in order to get to the message of the parable (Viljoen 2019:1-2; Zimmermann 2015:194-195).

In the end, virtually nothing short of the analysis of any narrative text is done on parables. This principle, in fact, enhances the exegete's consciousness that he or she is dealing with a narrative text, which, in turn, guides his or her choice of exegetical elements sought for from the text.

\section{Interpret what is given, not what is omitted}

Any attempt to interpret a parable based on what is not there is almost certainly wrong ... The more attention one gives to what is not there without evidence that the author intended some conclusion to be drawn the more one is almost certainly wrong. (Snodgrass 2008:29)

Attempt to read foreign ideas into biblical texts (called eisegesis) is common with interpreters and particularly so with parables. Those who set out to 'fill gaps' in biblical parables are here cautioned.

If, for instance, an exegete probes what happened after the elder brother to the 'prodigal' son got his father's explanation of the reason for celebration (Lk 15:32) - whether he changed his mind and attended the feast or not - that will be going too far. For the parable of the tenants (Mt 21:33-44), to ask how long it took for the owner of the vineyard to send the next servant (and finally his son) after the previous one was illtreated, could make a curious research focus, but has absolutely nothing to contribute to the meaning of the parable. Still for the story of the good Samaritan (Lk 10: 25-37), the man going from Jerusalem to Jericho was a Jew 14.According to Zimmermann, "narrative time' is 'the time taken to narrate the event', while 'narrated time' is 'the time it takes for the events in the narrative to transpire'. 
(at least, so as to increase the subversion of a socio-cultural convention in which a Samaritan assists was a Jew [cf. Lk 9:53; Jn 4:4-9])?

Such 'filled-in' details are not necessary for a parable to have meaning. The interpreter should therefore concentrate on information available in the parable text, and not presume to say more than it says. As Snodgrass mentioned before, the latter would certainly lead off tangent.

\section{Consider socio-historical background of the parables $^{15}$}

Parables are rooted in the reality of everyday life, but communicate their meaning when those social contexts are transferred into the religious domain. To that extent, a good number of the concepts found in the gospel parables are adopted from the social-historical context. One therefore needs to know the actual meaning of the concepts used and the processes described in the parables in order to understand the transformation process (Zimmermann 2015:196). How best should this be done? Zimmermann says the first thing is to explore the biblical texts themselves in which information on a parabolic concept can be gleaned from other biblical texts. After that, other relevant texts such as Jewish or Christian apocrypha, Hellenistic-Roman and rabbinical writings, as well as unwritten sources such as archaeological findings and coins, can be explored (Zimmermann 2015:198).

Taking the parable of the good Samaritan (Lk 10:25-37) for instance, the mention of 'Samaritan' in the narrative world alerts one to antagonism (cf. Lk 9:53; Jn 4:4-9). However, the point of the story is not Jewish-Samaritan antagonism, but to drive home the message of good neighbourliness. When this 'Samaritan' is characterised as a good neighbour, it leaves the Jewish religious leaders (and community) in the narrative without excuse, should they for whatever reason fail to fulfil the command to love their neighbours as themselves ( $\mathrm{Lk}$ $10: 27 b, 29)$.

Other concepts and processes whose socio-historical meanings are needed to enhance understanding of the parables when they appear, include Mammon (Lk 16:13), bread dough (Mt 13:33), loss of sheep (Lk 15:1-7), loss of a drachma (Lk 15:8-10), et cetera. Against the backdrop that ancient Jewish-Palestinian meanings and functions of concepts ${ }^{16}$ can differ from modern meanings and functions, Zimmermann (2015:196-197) warns that, 'The parables' reification and proximity to life can only be brought about through a connection to history'. By entering the 1st-century

15.It is often argued that, when reading the gospels as narratives, it should be read as historically with a text-immanent approach (Viljoen 2018:2). Edwards (1997:6) argues that there should be no concern for the historical background. Only the world in the narrative, as constructed by the narrative, is relevant. Such a nonreferential view of a narrative assumes that the narrative does not reflect the rea world. Although the narrative world of the gospels is not identical to reflections of the the world of Jesus or that of the evangelist, Edwards (1997:6) states, Undoubtedly of Jesus and the social world of the evangelist.' The reader must construct the real world from the narrative world.

16.The meaning of these concepts in the narrative world could differ from thei meaning within the environment in which the text originated that adds to the complexity to interpret them. world, the interpreter is able to familiarise him- or herself with plausible meanings of concepts, events and processes within that particular historical context, and is thus able to reasonably transfer meaning from that narrated world to the present one.

\section{Pay attention to stock metaphors and symbols}

Another window for gaining understanding of parables comprises stock metaphors and symbols. According to Zimmermann (2015):

Language does not start from scratch or with a tabula rasa since it is always already culturally conditioned ... Meaning is, in fact, closely bound to the use of a word in an historical and cultural context. (p. 199)

This is, according to Zimmerman, equally true of metaphors, which 'are extraordinary examples for the transformation of meaning'. However, he insightfully adds that, whereas a metaphor is constructed to explain a novel or unknown idea, 'the metaphoric text requires a traditional fixed meaning to be used within a new communication situation' (Zimmerman 2015:200).

So, for instance, when one comes across 'vineyard' in the parable of the unfaithful tenants (Mt 21:33-45) or 'king' in the parable of the feast (Mt 22:1-14), one wants to relate it to the linguistic culture of Israel. 'Vineyard' in the Old Testament refers to Israel as a nation (Is 3:14; 5:1-7; Jr 12:10), and this idea is carried over into the New Testament. 'King' refers to God, based on the stock symbolism in which 'king' referred to Yahweh (Nm 23:21; Is 33:22). Such knowledge of the narrative world immediately helps the reader to identify the characters in the narrative. The moment that happens, it is easy to understand the role of the character in the parable and how it may be interpreted in the image-receiving domain'.

\section{Pitfalls to avoid while interpreting the gospel parables}

Linked to these principles, it is also important to highlight some pitfalls that need to be avoided if interpreting the gospel parables. The following five issues are raised:

- Do not presuppose a parable's form or meaning.

- Do not seek to reconstruct the 'original' version of the parable.

- Do not impose 'real time' and 'logical time' on parable time.

- Do not interpret parables as historically factual events.

- Do not allegorise parables or deny allegorical features where they truly occur.

\section{Do not presuppose a parable's form or meaning}

Uninformed presuppositions with respect to parables can detract from their communicative intents. To guard against such detractions, Snodgrass (2008:25) advises that the interpreter should rather listen to the parables themselves 
and desist from presupposing their forms and meanings. He outlines specific pitfalls of presupposition as including an attempt to force a symmetric structure on a parable, the assumption that a parable must conform to some theory and imposing some theology on a parable.

Zimmermann's discussion (2009:167-169) on the form of parables as 'parable - nothing more' helps buttress the point. His critique of Jülicher and like-minded scholars for subdividing the parabolic genre into 'similitude', 'parable', 'example story' or 'figurative saying', et cetera, is rightly on the basis that the gospel writers never made such distinctions. ${ }^{17}$ Early Christian authors had no concept of subgenres of parables, but used $\pi \alpha \rho \alpha \beta 0 \lambda \eta \dot{~ i n ~ a ~ c o m p r e h e n s i v e ~}$ sense to refer to all of the so-called 'figurative sayings' (cf. Lk 5:36; 6:39), 'similitudes' (cf. Lk 14:7; 21:29), 'parables' (cf. Lk 8:4, 9, 11; Lk 18:1), 'example stories' (cf. Lk 12:16; 18:9), and so on.

The point in this for the present discussion is that interpreters who are convinced by some classification scheme would want to place every parable in one or other class. The consequence of this would be looking for some specific characteristics that align with such a class, but which may after all not be realistic with the parable in question. Such an approach would likely impose a form, as well as a message on the parabolic text being investigated. In the end, a different parable would have been created from the text. It is best, then, to deal with gospel parables in a comprehensive way; that way, they can speak for themselves.

\section{Do not seek to reconstruct the 'original' version of the parable}

For Snodgrass (2008:25), 'any attempt to reconstruct the original version of a parable is misguided'. Snodgrass' position fits a purely text-immanent approach..$^{18}$ However, it should be recognised that parables served as oral tools in much of an oral culture. In that sense, most of the parables would have been told and retold under dissimilar circumstances (Snodgrass 2017:136). To that extent, there can hardly be a plausible 'original' of any parable text. The modern reader has access to the parables via the gospels, but not to Jesus' ipsissima verba. 'Each individual source is a memory text that has remembered and preserved a version of Jesus' parables'. No gospel parable purports to be 'original' (Zimmermann 2015:189). In a text-immanent approach it is plausible to rather interpret the parables as recorded by the individual evangelists.

\section{Do not impose 'real time' and 'logical time' on parable time}

Snodgrass (2008:29) cautions that the 'narrative time' of a parable is not its 'real time chronology'. In other words, a

17.Zimmermann (2009:168) also rejects other forms of differentiation such as 'everyday events' versus 'extraordinary cases', 'general' versus 'individual' cases, those based on the so-called 'criteria of extravagance', et cetera. In his view, these differences are 'fluid'.

18. With a historical critical investigation earlier, layers and variants of parables will form a valid field of investigation. parable can have an extended chronology (e.g. Mt 22:1-14) or can breach chronology (e.g. Lk 14:15-24). Snodgrass similarly cautions against imposing 'logical time' on a parable, that is, trying to extend time and activities beyond the parable itself. In his (Snodgrass 2008) words:

When the parable is over, the narrative time is over. Thus to ask about events outside the story time ... destroys the parable and demonstrates misunderstanding about how analogies and parables work. (p. 30)

Take for instance the parable of the wedding feast (Mt 22: 1-14; Lk 14:16-24). The concluding plot in Matthew's version is the judgement (Mt 22:14) of the man who did not wear wedding clothes (vv. 11-12). But it was supposed to be a story about a wedding feast, and after eliminating the odd participant, the qualified guests should have continued with the feast. However, the story does not say anything about how the feast went after the man was cast out, or if it went on at all. While this is curious, it is nonetheless not useful for the purposes of the story. An interpreter who stretches beyond the given 'narrative time' has stepped beyond bounds and should return to the point where the narrative stops.

\section{Do not interpret parables as historically factual events}

The narrative claim of a parable is by nature both fictional and verisimilar (Akpan 2018:19-20; Zimmermann 2009:171). In other words, it is, on the one hand, a created (or invented) claim and cannot be accounted for as having happened at any time in human history. On the other hand, although an invented story, a parable demonstrates close affinity to reality in the sense that the event it describes could have happened that way in the narrated world. ${ }^{19}$

In light of the above, any approach that describes the parable event as if it were a historically factual event is the wrong starting point and will not produce a plausible interpretation. In fact, this pitfall usually leads to the tendency to want to fill gaps in the story. Because the story is erroneously regarded as a historical account, the interpreter may want to ask what happened between one scene and another, and could even lay emphasis on such assumed details.

The parable of the rich man and Lazarus (Lk 16:19-31) can serve as a good example to illustrate this mistake. For the simple reason that personalities (angels, Lazarus, Abraham, prophets and Moses) and real places (heaven and hell) are named in the story, it has often been mistaken for a historical account and its interpretation consequently made to follow historical lines. For instance, in the course of this work, I heard a preacher explain the story at a funeral service with emphasis on the rich man's wickedness. He alleged that the man's wickedness even got transferred to his dog so that, instead of concentrating on the crumbs from its master's

19.For this reason, Zimmermann (2009:171) rightly distinguishes parables from fantastic narratives, apocalyptic visions, fables and myths whose claims are impossible in the natural world. 
table, the dog rather licked Lazarus' sores with no rebuke whatsoever from its master. He also asserted that the rich man's proper name was omitted due to his wicked disposition, quoting Proverbs 10:7 in support of the claim: 'The memory of the righteous will be a blessing, but the name of the wicked will rot.' By that interpretation, the rich man's name was not worth preserving and therefore was omitted from the story so that it would not perchance be remembered. This and similar historically oriented interpretations can hardly be sustained.

\section{Do not allegorise ${ }^{20}$ parables or deny allegorical features where they truly occur}

In an allegory, every detail tends to have significance and is needed to achieve complete interpretation. ${ }^{21}$ Conversely, details in a parable are not all equally significant in meaning. Some of the details serve only to 'garnish' and 'colour' the story and nothing more. Therefore, any attempt to assign meaning to all details of a parable ends up allegorising it. A classic example is Augustine's allegorical interpretation of the parable of the Good Samaritan ${ }^{22}$ (cf. Lk 10:30-37), which has, since Jülicher, been rejected (Snodgrass 2008:4). This kind of interpretation, Herrick (2004:1) says, 'has disastrous affects [sic] on the practical authority of the Bible for its message becomes completely obscured and there is no reasonable method whereby we can adjudicate between competing interpretations.' It should therefore be avoided at all cost.

Caution against the allegorising of gospel parables does not, however, threaten obvious allegorical terms in some of them. However, while Jülicher completely repudiated allegory ${ }^{23}$ in a bid to correct the wanton allegorising liberties that characterised the period before him, modern scholars have successfully 'rehabilitated' allegory and now accommodate the allegorical features found in some parables (Herrick 2004:1; Zimmermann 2009:166). Hultgren (2000:14), in fact, identifies some specific terms in the parables of Jesus that have metaphoric meanings and should be understood as such, for example father, king, servant, et cetera. He proposes that, as soon as these terms are noticed, one cannot but admit to the presence of some allegorical elements in such parables:

20.Zimmermann (2015.37) explains the differences between allegory allegorising and allegorisation: Allegory is defined as a poetic process for the illustration of nonsensual contents'; allegorising as 'the allegorical rereading of a text that did not riginally have any allegorical as 'the allegorical rereading of a text that did (n) 2006:143).

21.Biblical examples of an allegory include 'The Song of the Vineyard' (Is 5) and the Contrast between the Freewoman and the Bondwoman (GI 4:22-31).

22.In Augustine's scheme, the man is Adam; Jerusalem the heavenly city; Jericho, the moon (representative of morality); the robbers represent the devil and his angels: they strip the man of his immortality and beat him by persuading him to sin; the priest and levite represent the priesthood and ministry of the Old Testament; the good Samaritan is Christ; the binding of the wound is the restraint of sin; the oil and wine are the comfort of hope and the encouragement to work: the donkey is the incarnation: the inn is the church; the next day is after the resurrection of Christ; the innke Christ; the ints of (Snodgrass 2008:4).

23.According to Reinstorf (2006:142), Jülicher rejected the allegorical approach to Jesus' parables on the premise that 'allegory "disguises meaning"' - a situation that, for him (Jülicher), could not easily reconcile with Jesus' intention with his stories. (e.g. 'father' = God [Lk 15:11-32]; 'king' = God [Mt 22:1-13]). Furthermore, some of the parables of Jesus are in fact thoroughly allegorical in nature, for example 'the Wicked Tenants' (Mk 12:1-12), 'the Wedding Feast' (Mt 22:1-14), and 'the Great Banquet' (Lk 14:16-24).

Others have recognisable allegorical elements embedded in them such as the city that is destroyed in the parable of 'the Marriage Feast' (Mt 22:1-14), and the shepherd in the parable of 'the Final Judgement' (Mt 25:31-46). Still, Hultgren continues that others carry allegorical interpretations appended to them, for example the interpretations of the parable of 'the Sower' (Mk 4:13-20) and 'the Dragnet' (Mt 13:49-50).

Hultgren then insightfully advises that interpreters of the gospel parables should recognise and respect allegorical elements wherever they exist, but also be wary of arbitrarily assigning allegorical meanings to symbols or figures within the text. Reinstorf (2006:143) also adds: 'The real problem is not allegory, but allegorizing.' These submissions should be received in good faith by parable scholars. Where allegorical features are found in a parable, they should be approached as such; and where they are not found, none should be manufactured.

\section{Conclusion}

This article concludes that not all interpretations of the gospel parables are plausible. Although the parables lend themselves towards polyvalent interpretation, openness does not validate arbitrary interpretations. Gospel parable interpreters therefore need to take seriously methods and principles that limit multiplicity and enhance credibility of meanings of the parables. The principles as set forth above, constitute a helpful contribution to this goal. It needs also to be stated that the principles as identified above, simultaneously complement and countercheck one another, and therefore need to be holistically accounted for. That way, they will boost the confidence of interpreters, as well as limit the excesses that come with parable interpretation.

\section{Acknowledgements Competing interests}

The authors declare that they have no financial or personal relationships that may have inappropriately influenced them in writing this article.

\section{Author's contributions}

A.M.A. and F.P.V. contributed equally to the design and implementation of the research, to the analysis of the results and to the writing of the manuscript.

\section{Ethical considerations}

This article followed all ethical standards for research without direct contact with human or animal subjects. 


\section{Funding information}

This research received no specific grant from any funding agency in the public, commercial, or not-for-profit sectors.

\section{Data availability}

The authors confirm that the data supporting the findings of this study are available within the article.

\section{Disclaimer}

The views and opinions expressed in this article are those of the authors and do not necessarily reflect the official policy or position of any affiliated agency of the authors.

\section{References}

Akpan, A.M., 2018, 'Evaluation of Pentecostal interpretations of Matthew 25:14-30 in the light of reformed hermeneutics', MA dissertation, Faculty of Theology, NorthWest University, Potchefstroom Campus.

Dodd, C.D., 1961, The parables of the kingdom, rev. edn., Charles Scribner's Sons, New York, NY.

Edwards, R.A., 1997, Matthew's narrative portraits of disciples, Trinity Press International, Harrisburg.

Gerhardsson, B. 1991 'If we do not cut the parables out of their frames', New Testament Studies 37(3), 321-325. https://doi.org/10.1017/S0028688500015903

Herrick, G., 2004, The interpretation of parables: Exploring 'imaginary gardens with real toads', viewed 14 September 2020, from https://bible.org/article/ interpretation-parables-exploring- $\%$ E2 $\% 80 \% 9$ Cimaginary-gardens-realtoads $\% \mathrm{E} 2 \% 80 \% 9 \mathrm{D}$

Herzog II, W.R., 1994, Parables as subversive speech: Jesus as pedagogue of the oppressed, Westminster/John Knox Press, Louisville, KY.

Howell, D.B., 1990, 'Matthew's inclusive story: A study in the narrative rhetoric of the first Gospel', Journal for the Study of the New Testament suppl. ser. 42, 19-32.

Hultgren, A.J., 2000, The parables of Jesus: A commentary, William B. Eerdmans, Grand Rapids, Ml.
Lategan, B., 2009, 'New Testament Hermeneutics (part II): Mapping the hermeneutical process', in A du Toit (ed.). Focusing on the message: New Testament process, in A. du Toit (ed.), Focusing on the message: New
hermeneutics, exegesis and methods, pp. 66-105, Protea, Pretoria.

Reinstorf, D.H., 2006, 'The Challenge of Jesus' parables: A scholarly handbook for ministers and preachers', HTS Teologiese Studies/Theological Studies 62(1), 139-154. https://doi.org/10.4102/hts.v62i1.352

Roth, D.T., Zimmermann, R. \& Labahn, M. (eds.), 2014, Metaphor, narrative and parables in Q, Mohr Siebeck, Tubingen.

Scott, B.B., 1989, Hear then the parable: A commentary on the parables of Jesus, Augsburg Fortress, Minneapolis, MN.

Snodgrass, K.R., 2008, Stories with intent: A comprehensive guide to the parables of Jesus, William B. Eerdmans, Grand Rapids, MI.

Snodgrass, K., 2017, 'Are the parables still the bedrock of the Jesus tradition?', Journal for the Study of the Historical Jesus 15(1), 131-146. https://doi.org/ 10.1163/17455197-01501002

Tompkins, l., n.d. a, Parable of the talents: What have you done with what I gave you? viewed 09 March 2018, from http://www.ivernainternational.com/teaching/ pott01.php

Tompkins, I., n.d. b, Parable of the talents: What have you done with what I gave you?, viewed 09 March 2018, from http://www.ivernainternational.com/teaching/ pott02.php

Tompkins, I., n.d. c, Parable of the talents: What have you done with what I gave you? viewed 09 March 2018, from http://www.ivernainternational.com/teaching/ pott03.php

Van der Watt, J., 2009, 'Reading New Testament imagery', in A. du Toit (ed.), Focusing on the message: New Testament hermeneutics, exegesis and methods, pp. 305-340, Protea, Pretoria.

Van Eck, E., 2009, 'Interpreting the parables of the Galilean Jesus: A social-scientific approach', HTS Teologiese Studies/Theological Studies 65(1), 1-12. https://doi.org/ 10.4102/hts.v65i1.308

Viljoen, F.P., 2018, 'Reading Matthew as a historical narrative', In die Skriflig 52(1), a2390. https://doi.org/10.4102/ids.v52i1.2390

Viljoen, F.P., 2019, 'Why Jesus spoke in parables', In die Skriflig 53(1), a2523. https://doi.org/10.4102/ids.v53i1.2523

Zimmermann, R., 2009, 'How to understand the parables of Jesus: A paradigm shift in parable exegesis', Acta Theologica 29(1), 157-182. https://doi.org/10.4314/actat. v29i1.44175

Zimmermann, R., 2014, 'Metaphorology and narratology in Q exegesis: Literary methodology as an aid to understanding the $Q$ text', in D.T. Roth, R. Zimmermann \& M. Labahn (eds.), Metaphor, narrative and parables in Q, pp. 3-30, Mohr Siebeck, Tubingen.

Zimmermann, R., 2015, Puzzling the parables of Jesus: Methods and interpretation, Fortress Press, Minneapolis, MN. 